
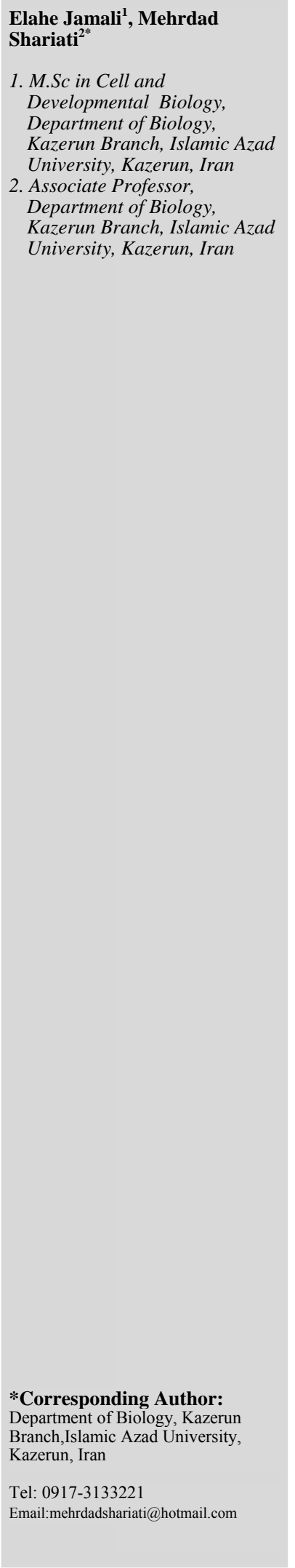

\section{The Study of Testicular Deveplopment in Newborn Male Rats from the Mothers Treated with Maprotiline Hydrochloride Drug}

Received: 15 Jul. 2017; Accepted: 4 Jan. 2018

Background: Maprotiline hydrochloride is a norepinephrine reuptake inhibitor; that is using for the treatment of depression. In this research, were studied the effect of maprotiline on changes of the testicular tissue and the concentration of testosterone and gonadotropins in newborn male rats from the mothers treated with this drug.

Materials and Methods: In this experimental study, 40 newborn male rats wistar strain, from pregnant mothers that received 30,60 and $90 \mathrm{mg} / \mathrm{Kg}$ of maprotiline hydrochloride in the three experimental groups orally for pregnancy period that is 21 days. Divided to 5 group of 8 animals. The control group received nothing, and the sham group received solvent. In 22th days after parturition, the newborns weighted and blood samples were taken from the hearts, and concentrations of FSH, LH and testosterone were measured by RIA method. The newborns testes were separated and histological changes were studied. Results: 60 and $90 \mathrm{mg} / \mathrm{kg}$ of maprotiline hydrochloride can be reduced significantly testosterone levels while it increased significantly LH levels compare with control group $(p<0.05)$. FSH levels don't showed significant changes between the experimental and control groups. Histological examination showed a significant decrease in the sperm density, the number of spermatogonia, primary spermatocytes, spermatids and leydig cells in the experimental groups receiving 60 and $90 \mathrm{mg} / \mathrm{kg}$ of the drug, compared to the control group. Also in the experimental groups receiving the drug, with increasing amounts of the drug, decreased body weight and testes weight compared to the control group.

Conclusion: 60 and $90 \mathrm{mg} / \mathrm{kg}$ of maprotiline hydrochloride decreases significantly the concentration of testosterone and the number of spermatogenic cells and increases LH levels.

Keywords: Maprotiline hydrochloride, Gonadotropins, Testosterone, Newborn rat 


\section{بر رسى تكوين بيضه نوزادان موشهاى صحرايى متولد از مادران تحت تيمار با داروى مايروتيلين هيدرو كلرايد}

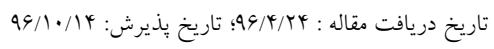

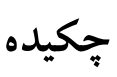

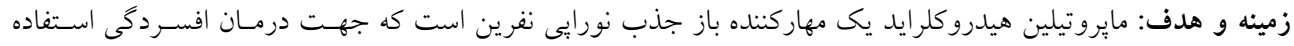

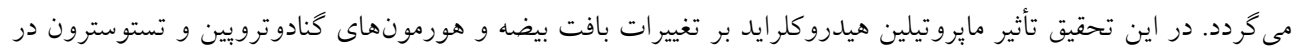
نوزادان موش صحرايى متولد از مادران تحت تيمار با اين دارو بررسى كرديد.

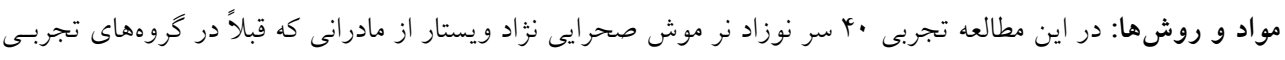

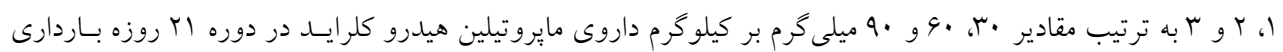

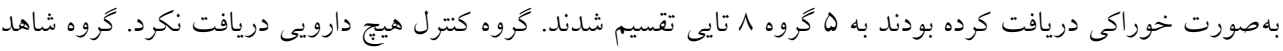

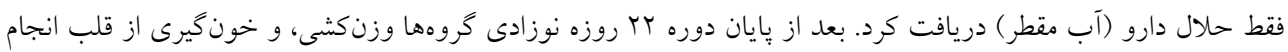

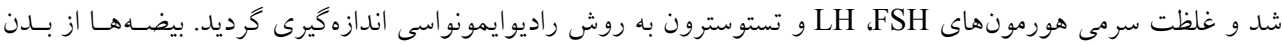

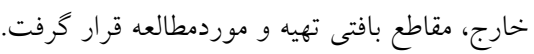

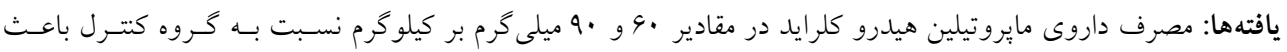

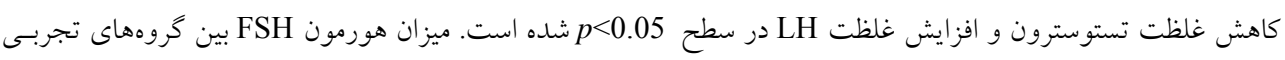

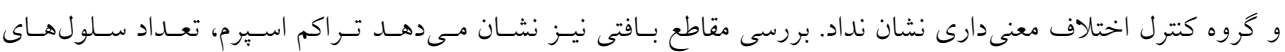

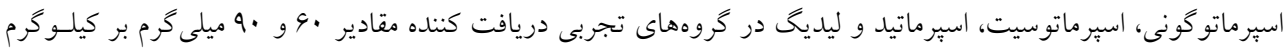

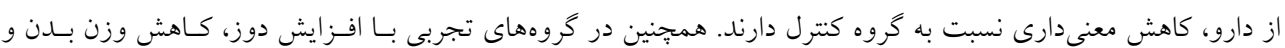

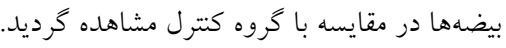

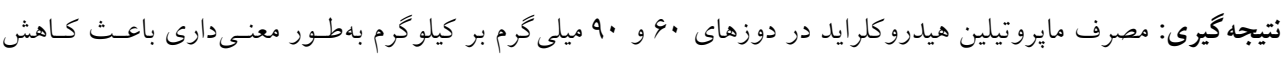

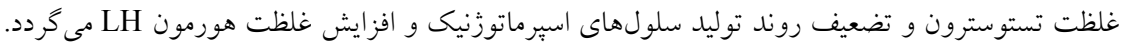

كلمات كليدى: مايروتيلين هيدروكلرايد، كنادوترويين، تستوسترون، نوزاد موش صحرايى rالهه جمالى'! مهرداد شريعتى

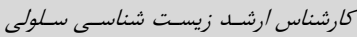

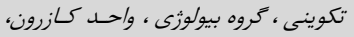

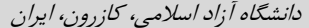

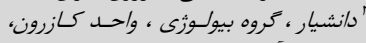

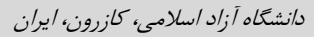

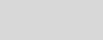




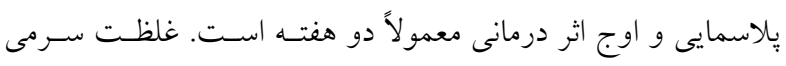

مقدمه

درمانى فرض شده

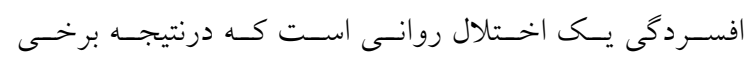

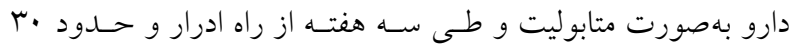

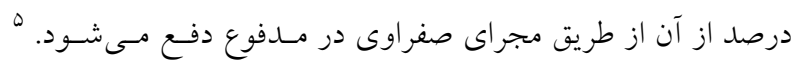

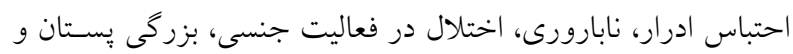

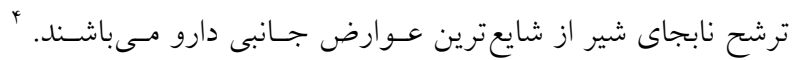
مايروتيلين بر اساس تقسيمبندى سـازمان غــا و داروى آمريكـا، در كروه B قرار مى گيرد. با توجه به اينكه مطالعات كافى در زنان باردار

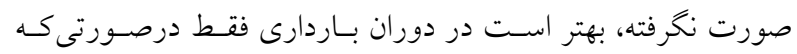
مصرف آن ضرورى باشد استفاده شود و با توجه بـه اينكسه در شـير مادر با غلظت مساوى يا بيشتر ازسرم مـادر ترشـح مسىشـود، بايسـا

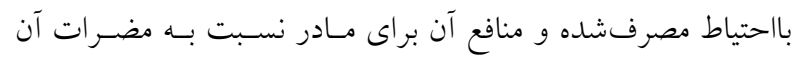

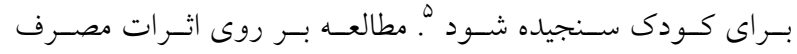
مايروتيلين در درمان افسردگى طيف گستردهاى از بيماران انجامشده است. گزارش هايى وجود دارد كه نشاندهنده تأثير مفيد اين دارو در

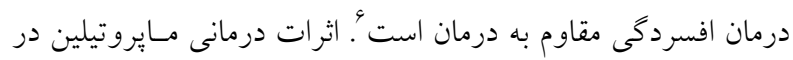

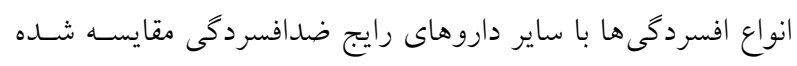

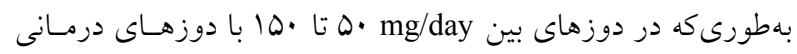

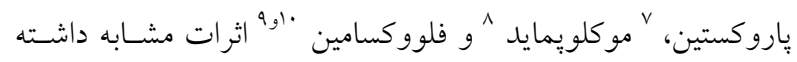
است. در مطالعهاى كه به بررسى تأثير داروى مإيروتيلين بر روى 90

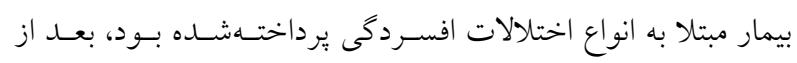

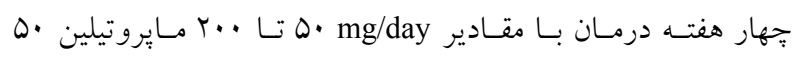
درصد بيماران به بهبودى كامل و ب M درصد به بهبودى نسبى دست

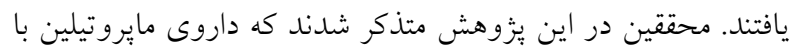
دوز حســاكثر mg/day • 10 دارويسـى مـؤثر در درمــان اخــتلالات

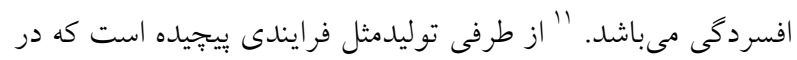

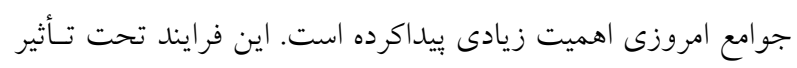
عوامل مختلفى قرار مى گيرد. عوامل هورمونى درونريسز عصـبى بــا تنظيم فعاليت واسطههاى شيميايى مى تو انند نقش مؤثرى در توليدمثل موردي داشته باشند. بسيارى از واسطههاى شيميايىبر محور هيبوتسالاموس -

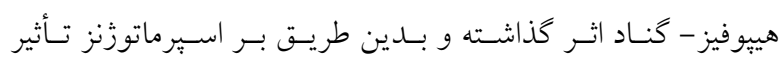
مى كذارند. جهش در بيان زنهاى موجود در محسور هيبوتسالاموس-

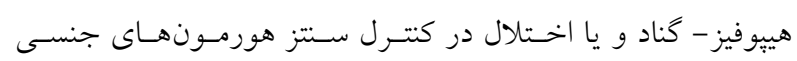

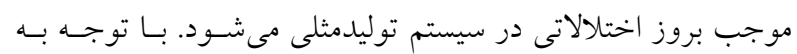
فعلوانفعالات شيميايى در مغز اتفاق مىافتـد و درمجمـوع بـيش از هادرصد از افراد را در طول عمر خود مبتلا سـاخته اسـت. نـورايى نفرين و سروتونين دو نوروترانسميتر از نوع آمين زيستى هستند كـــ

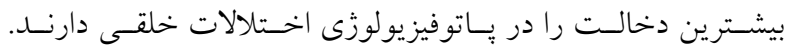
افزايش اين نوروترانسميترها منجر به اضطراب و كاهش آنها منجـر

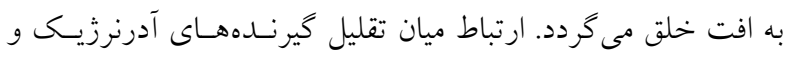

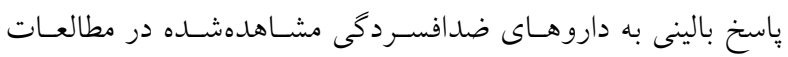

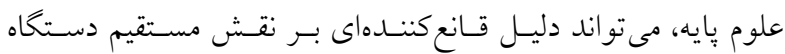
'نور آدرنرزيك در افسردگى بايهى بواشد.' مايروتيلين هيدرو كلرايد (بانام تجـارى Ludiomil) از داروهـاى

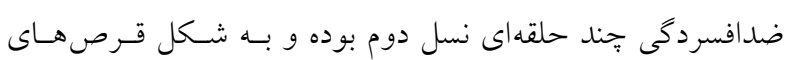
روكشدار هT و VD ميلى کرمى جهت درمان طولانىمدت افسردگى، همجنين درمان افسردگى توأم با اضطر اب مورداستفاده قرار مى گيرد.

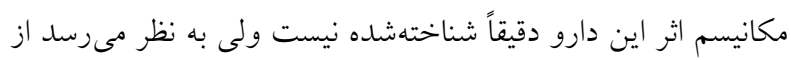

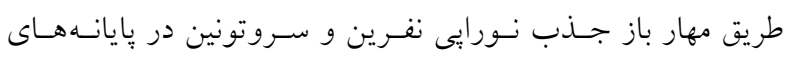
عصبى نورونهاى بيش سينايسى اثر خود را اعمال مى كنــ، كـه بــه

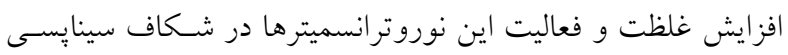

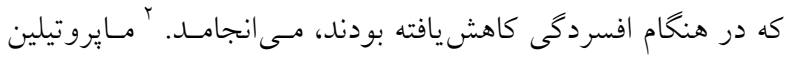
همجنين آنتاكونيست قوى گيرنده Histamine، آنتاكونيست متوسط

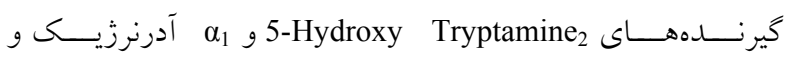
أنتاكونيست ضعيف كيرندهاى Duscarinic Acetyl و Dopamine Cholinergic كيرنده

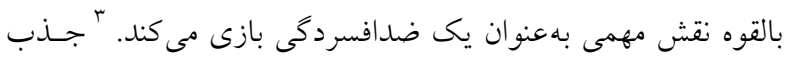

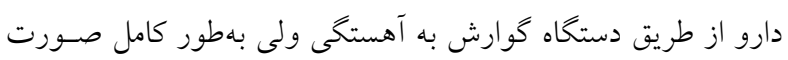

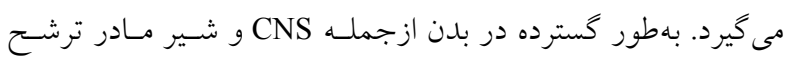

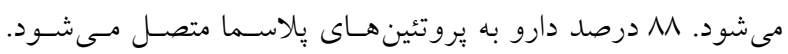

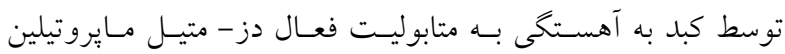
متابوليزه مىشود. اين دارو اثر عبور اوليه قابل ملاحظـه كبـدى دارد.

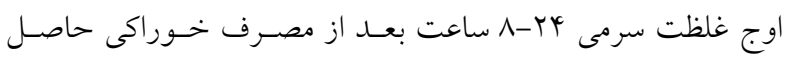

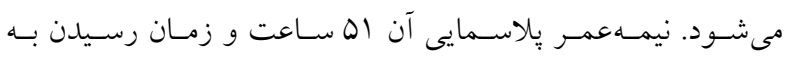

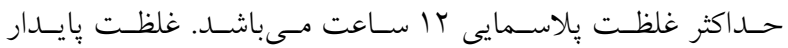


كردند. و كروههاى تجربى 1، ب و ب هركدام شامل هـ سر موش ماده

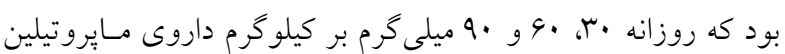
دريافت مىكردند. در هر قفس ؟ّ موش نر يك هفتـه جهـت بـاردار

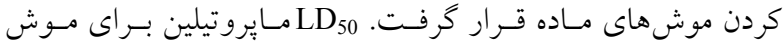

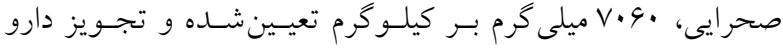
بهصورت خوراكى (دهـانى) در طـول دوره الب روزه بـاردارى و در ساعت مشخصى از روز صورت مى گرفت. بعد از زايمـان، نسوزادان

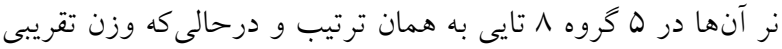

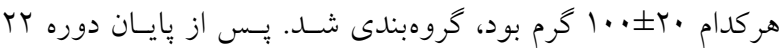

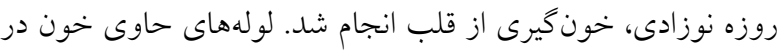
دستخاه سانتريفيوز به مدت 10 دقيقه با سرعت ل..01 دور در دقيقهـ

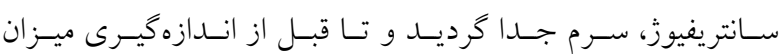
هورمونهاى FH و FH و تستوسترون در فريزر در دماى •r درجسه

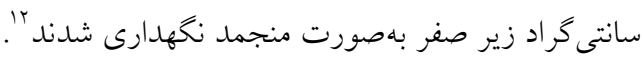

\section{روش سنجش هورمونى}

براى اندازهكيرى غلظت هورمونهاى FSH، LH و تستوسترون از روش راديوايمونواسى استفاده شد. اساس اين روش رقابت ميـان آنتى زن موجود در نمونه سنجش براى اتصال به آنتىبادى است كـهـ

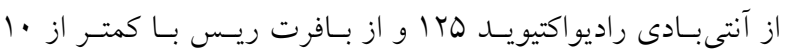
درصد سديم آزاد استفاده مىشود.

\section{آزمايش هاى بافتشناسى}

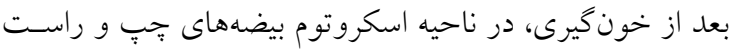

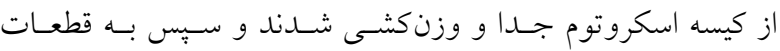

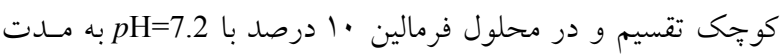

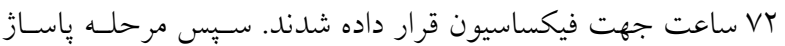

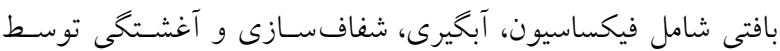

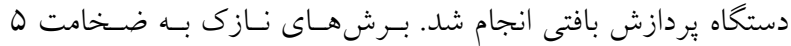

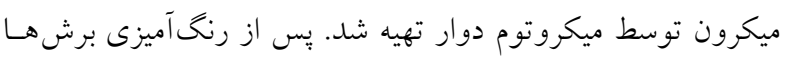

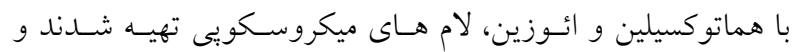

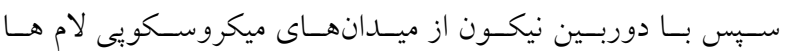

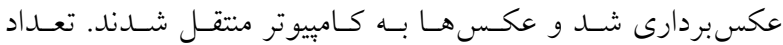

افزايش شيوع افسردكى در جامعه ازجمله در زنان باردار و استفاده

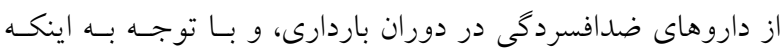

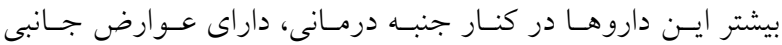
كو تامدات و يا درازمدت بىشمارى هستند كه مصرف آنها در ايسن

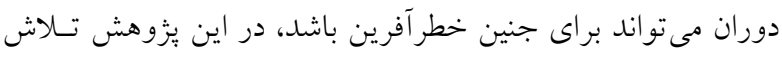

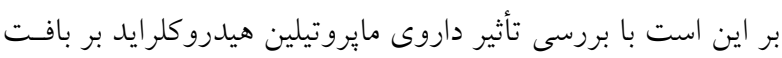

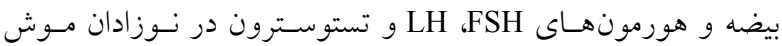

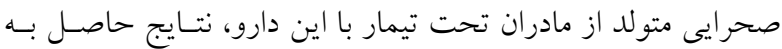

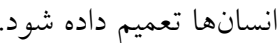

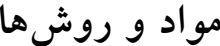

حيوانات مورداستفاده در اين يُزوهش، •l سر نسوزاد نــر مـوش

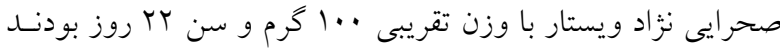

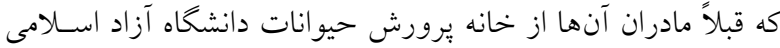
واحد كازرون تهيـه و در دوره بـاردارى توسط داروى مـايروتيلين

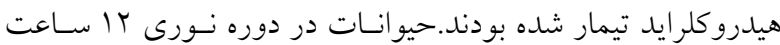

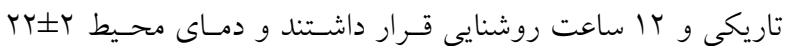
درجه سانتى گراد و در طول شبانهروز ثابت بود. آب و غذا در تمـام

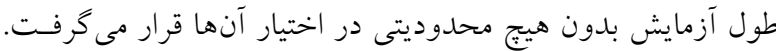

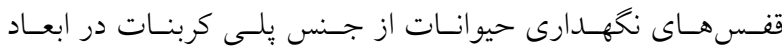

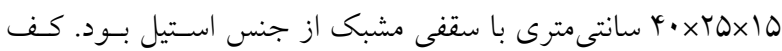

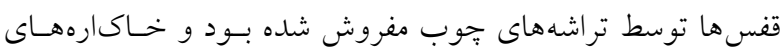
موجود در كـف قفس هـر دو روز تعـويض و توسطط آب و مـواد ضدعفونى كنده شستشو مىشدند. آب مصرفى، آبلوله كشى شهرى، غذاى مادران، غذاى مخصوص موش و غذاى نسوزادان، شـير مـادر

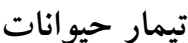

موشهاى مادر در ه كـروه ه تايى بـهــورىكـه وزن تقريبـى

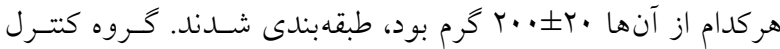

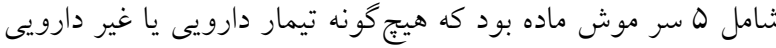

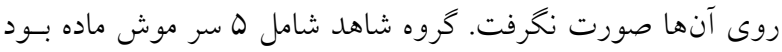

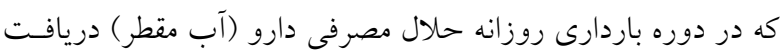




\section{يافته ها}

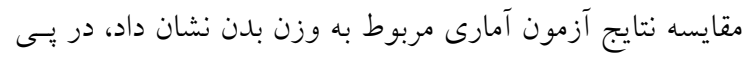

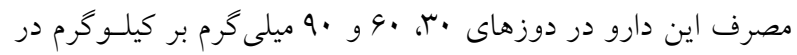

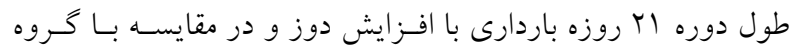

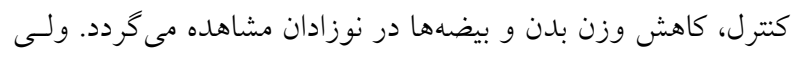

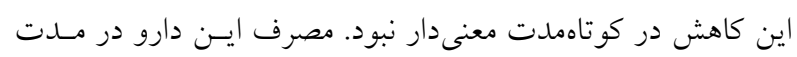

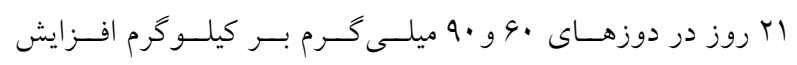

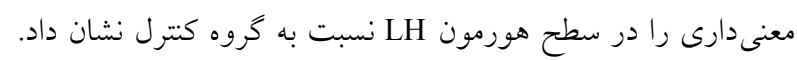

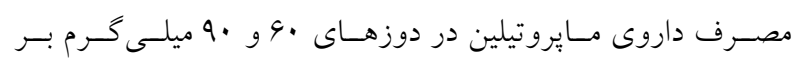

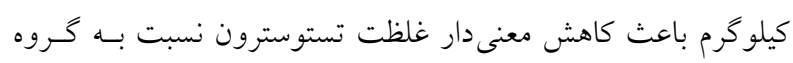

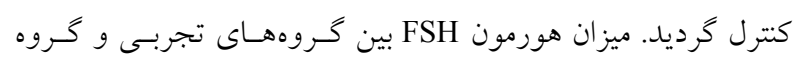

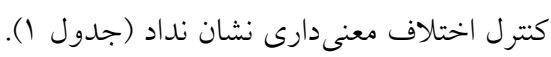

سلول هاى اسيرماتوكونى، اسيرماتوسيت و اسيرماتيد، سلوله لمهاى

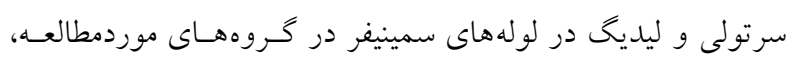

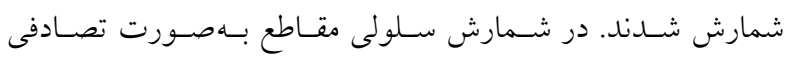

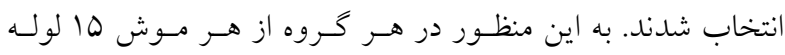

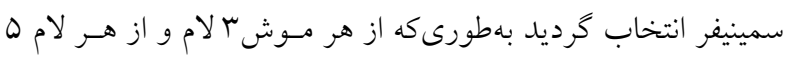

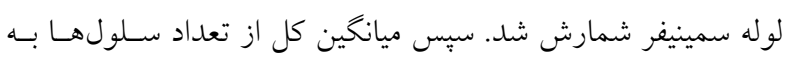
دست آمد و دادهها ازنظر آمارى مورد مقايسه قرار كرفتندي.

آناليز آمارى

نتايج بهدست آمده با استفاده از برناهه آمارى SPSS و و تستهاى

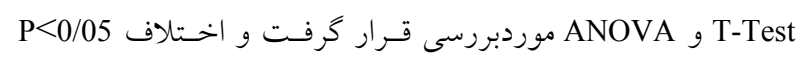
معنى ار، در نظر كرفته شد.

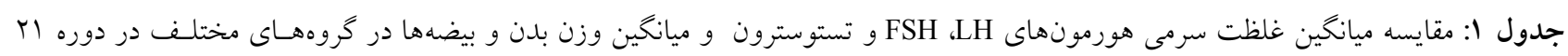

\begin{tabular}{|c|c|c|c|c|c|c|}
\hline $\begin{array}{l}\text { ميانخين وزن } \\
\text { (g) } \\
\text { (g) }\end{array}$ & 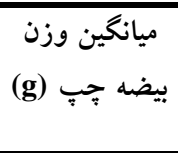 & $\begin{array}{l}\text { ميانگين وزن } \\
\text { (g) }\end{array}$ & غلظت هورمون & $\begin{array}{c}\text { غلظت هورمون } \\
\text { FSH (mIU/L) }\end{array}$ & تستوسترون (ng/ml تورمون & 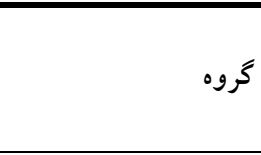 \\
\hline$\cdot / 9 r \pm \cdot / \cdot V$ & $.194 \pm .1 .9$ & $99 / r \cdot \pm r / \wedge 9$ & $\vee / 9 \Lambda \pm \cdot / 1 \Lambda$ & $r / 9 \Lambda \pm \cdot / \mu$. & $0 / 4 \cdot \pm \cdot / 19$ & كنترل \\
\hline$\cdot / 19 \pm \cdot / \cdot 9$ & $\cdot / \wedge q \pm \cdot / \cdot \vee$ & $Q / / 4 \cdot \pm \Delta / \Lambda)$ & $V / V Y \pm \cdot / T$ & $T / M T \pm \cdot / r \mu$ & $0 / 4 \mathcal{F} \pm \cdot / 19$ & شاهد \\
\hline$\cdot / \wedge \omega \pm \cdot / \cdot \varphi$ & $\cdot / \Lambda V \pm \cdot / \cdot 9$ & $\Lambda q / \Lambda \Lambda \pm Q / T Y$ & $V / V 4 \pm \cdot / 11$ & $Y / Y Y \pm \cdot / Y I$ & $\varphi / A r \pm \cdot / 19$ & تجربى ا (30 mg/kg) \\
\hline$\cdot / \Lambda \mid \pm \cdot / \cdot \psi$ & $\cdot / \Lambda r \pm \cdot / \cdot \Delta$ & $\Lambda \varepsilon / \vee Q \pm r / r q$ & $\Lambda / r \cdot \pm \cdot / \cdot \wedge *$ & $r / 19 \pm \cdot / r 1$ & $4 / 10 \pm \cdot / 19 *$ & تجربى ץ (60 mg/kg) \\
\hline$\cdot / V \Lambda \pm \cdot / \cdot \psi$ & $\cdot / \Lambda \mid \pm \cdot / \cdot \varphi$ & $\Lambda \uparrow / r \Lambda \pm r / 4 \uparrow$ & $\wedge / \vee q \pm \cdot / \cdot \wedge *$ & $Y / T Y \pm \cdot / K$ & $r / \wedge q \pm \cdot / / \wedge *$ & تجربى ץ (90 mg/kg) \\
\hline
\end{tabular}

جدول ب: مقايسه ميانحين تعداد سلولهاى اسبرماتو گونى، اسبرماتوسيت اوليه، اسبرماتيد و سرتولى در يك لوله سـمينيفر و ليـديخ در خـروههـاى مختلف در دوره آ روزه باردارى

\begin{tabular}{|c|c|c|c|c|c|}
\hline $\begin{array}{c}\text { تعداد سلولهاى } \\
\text { ليديخ }\end{array}$ & سلول ميانگين تعداد & 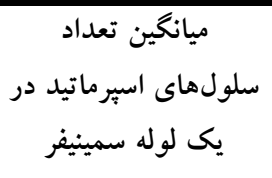 & اسيرماتوسيت اوليه در سلولهاى & تعداد سلولهاى & كروه \\
\hline$\Gamma 1 / 9 \cdot \pm 1 / \pi 4$ & $19 / 4 \cdot \pm 1 / \Gamma^{4}$ & $\mid r N / A \cdot \pm 1 / \Delta r$ & $V q / \cdots \pm r / \cdot V$ & $G \cdot / \Lambda \cdot \pm T / M T$ & كنترل \\
\hline$r Y / \Lambda \pm \pm 1 / \bullet \wedge$ & $1 / / \Lambda \cdot \pm 1 / 0 \cdot$ & $1 / r q / 9 \cdot \pm 1 / r q$ & $V Q / \mathcal{H} \cdot \pm r / \mathcal{A} r$ & $9 \cdot / r \cdot \pm r / r \cdot$ & شاهد \\
\hline$|9 / T| \pm \cdot / 1 \mid$ & $r r / I Y \pm 1 / Q r$ & $1 Y Y / 99 \pm 1 / 99$ & $V \cdot / \wedge G \pm I / V Q$ & $\Delta F / \Lambda G \pm 1 / 9 \Lambda$ & تجربى ا (30 mg/kg) \\
\hline $\mid r / q \Psi \pm \cdot / V Q *$ & $1 N / 0 \cdot \pm \cdot / q r$ & $\| 10 / 9 \mu \pm 1 / 01^{*}$ & $G \psi / \Gamma \wedge \pm 1 / 1 \mu *$ & $\kappa \mu / r \Delta \pm 1 / \Delta \cdot *$ & تجربى ץ (60 mg/kg) \\
\hline $11 / 1 r \pm \cdot / 9 \cdot *$ & $19 / 94 \pm \cdot / 91$ & $1 \cdot \Lambda / \mu \wedge \pm 1 / 1 \mu^{*}$ & $91 / 0 \cdot \pm 1 / \pi r^{*}$ & $r q / v \Delta \pm 1 / \mu \mu^{*} *$ & تجربى ץ (90 mg/kg) \\
\hline
\end{tabular}


تيمار در مقايسه با گروه كنترل و با افزايش دوز دارو تغييراتى ازنظر

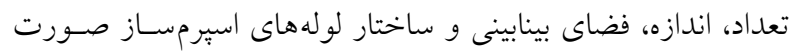

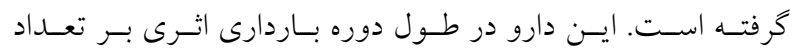

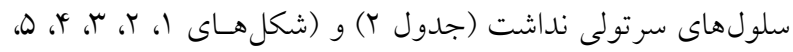
.( $\wedge, \vee 9$
در بررسى مقـاطع بــافتى بيضـه، كـاهش معنسىدارى در تـراكم

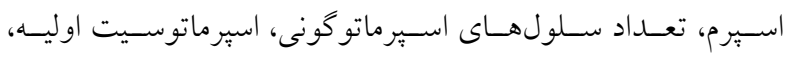
اسيرماتيد و نيز سلولهاى ليديخ در گروههاى تجربى دريافت كننده

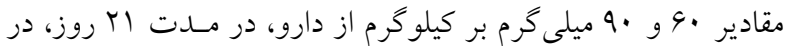

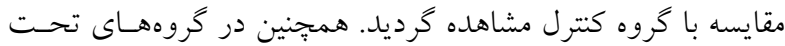

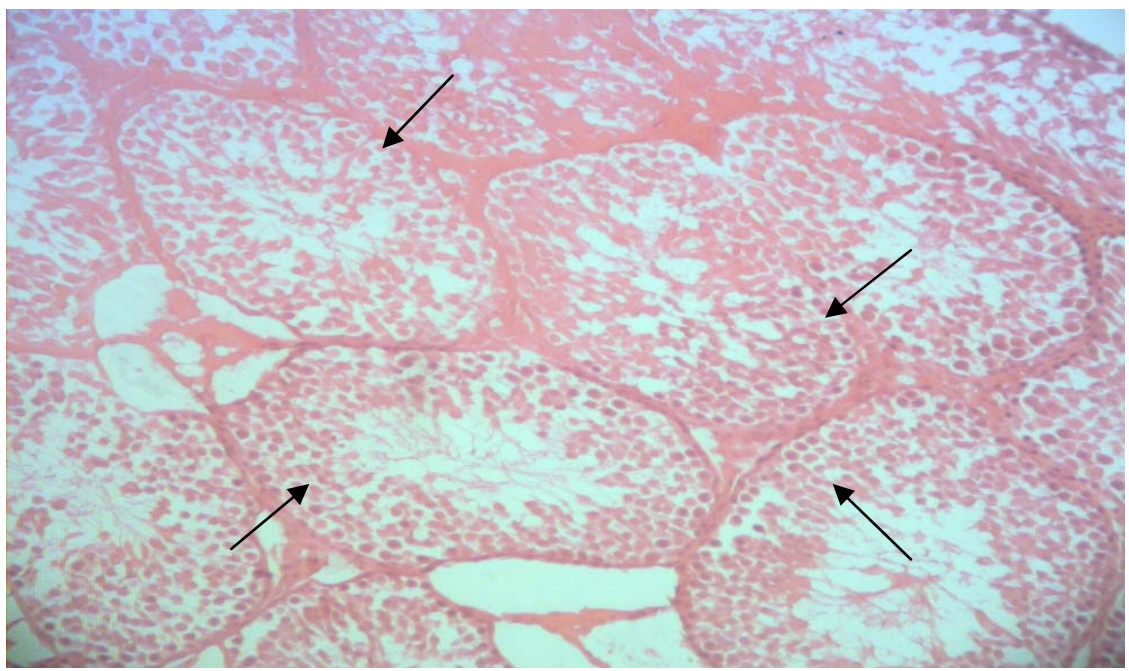

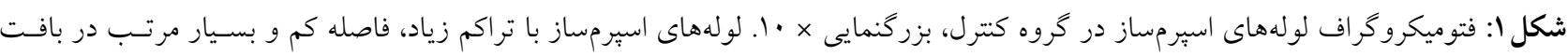
بيضه مشاهده مىشوند. علامت فلش نشاندهنده ابى تليوم سلولهاى زرمينال مىباشد.

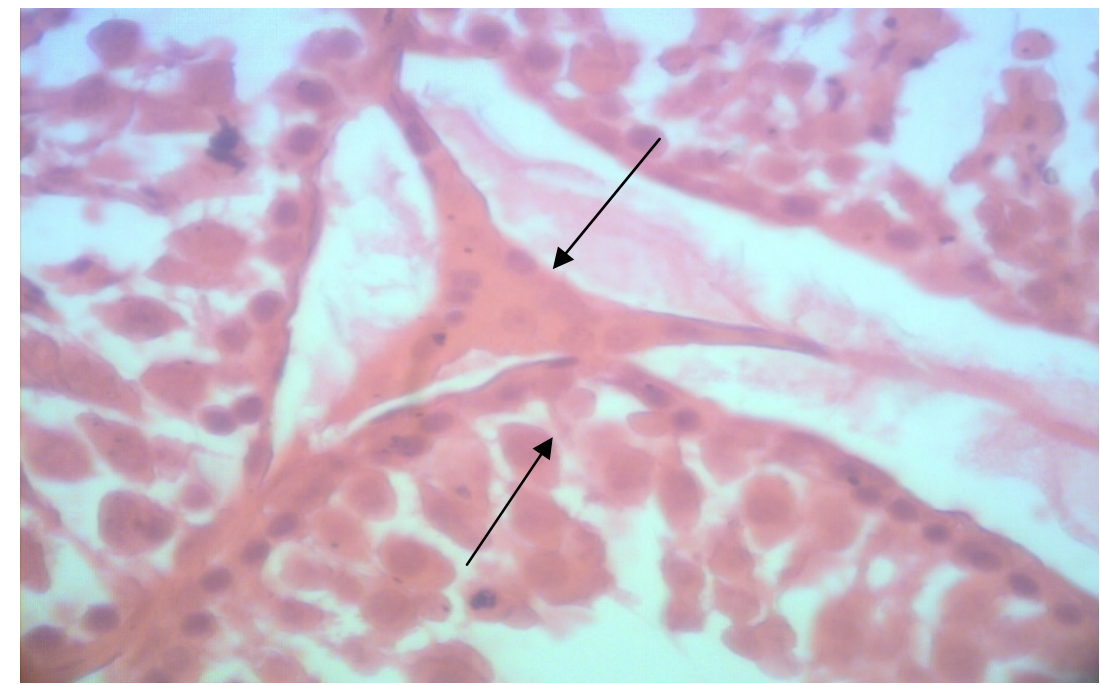

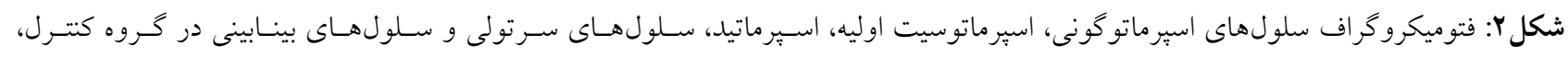

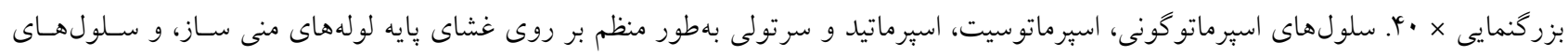
ليديخ بهصورت تودهاى در كنار هم قرارگرفتهاند. علامت فلش نشاندهنده ايى تليوم سلولهاى زرمينال و محـل قرارگيـرى سـلولهـاى ليـديخ 


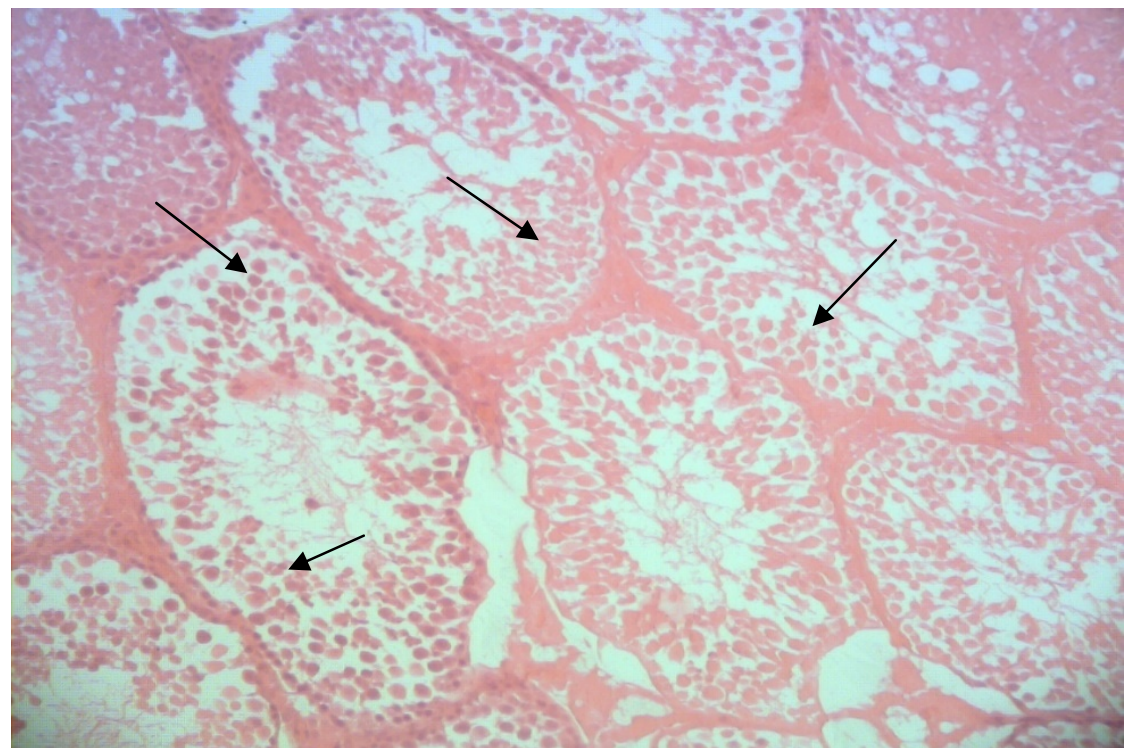

شكل r: فتوميكروكراف لوله هاى اسيرمساز در گروه تجربى ا، بزرگنمايى × • ا. تغييرات بافتى ازنظر تعداد، ساختار و شكل در لولههاى اسبرمسـاز نسبت به كروه كنترل صورت نخرفته است. علامت فلش نشاندهنده إيى تليوم سلولهاى زرمينال مى باشد.

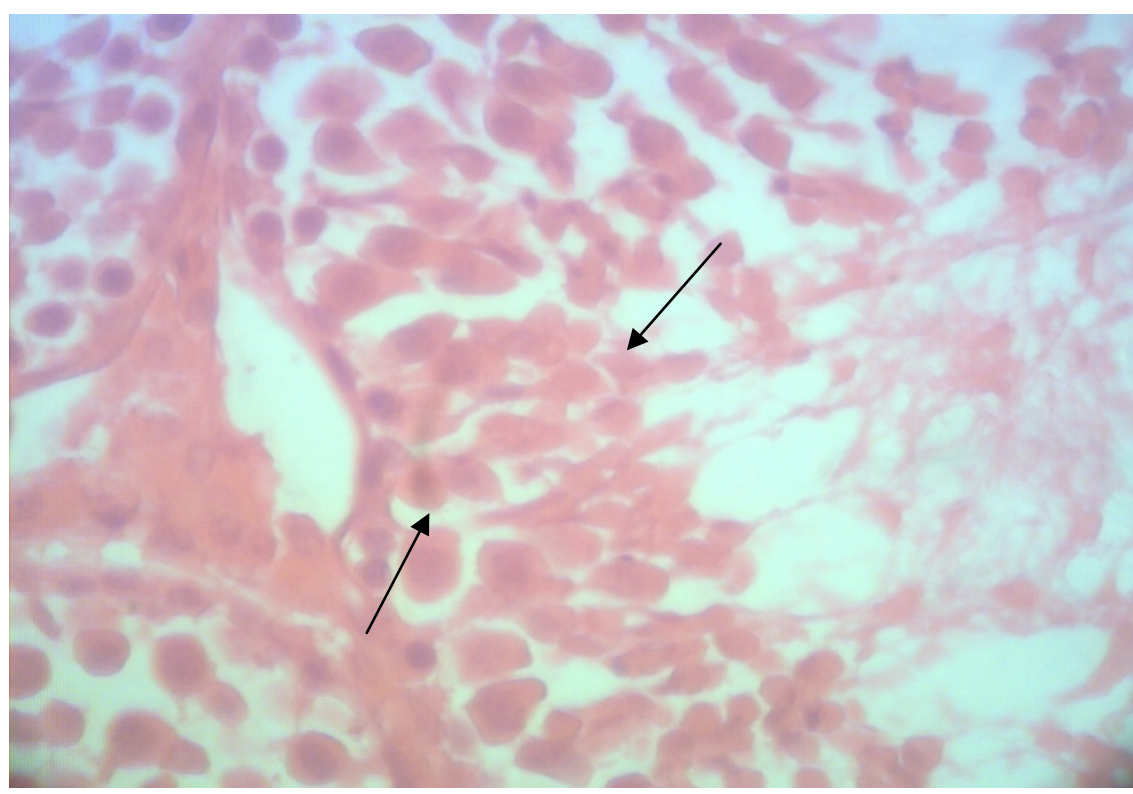

شكل ثا: فتوميكرو كراف سلولهاى اسيرماتوكونى، اسبرماتوسيت اوليه، اسبرماتيد، سلولهـاى سـرتولى و سـلولهـاى بينـابينى در گـروه تجربسى ا،

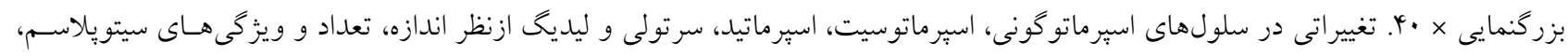

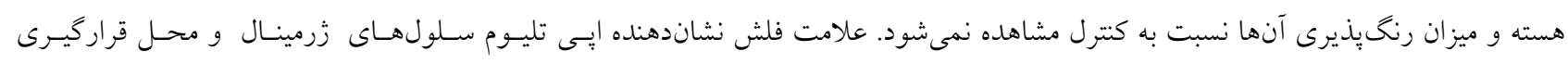
سلولهاى ليديخ مى باشد. 


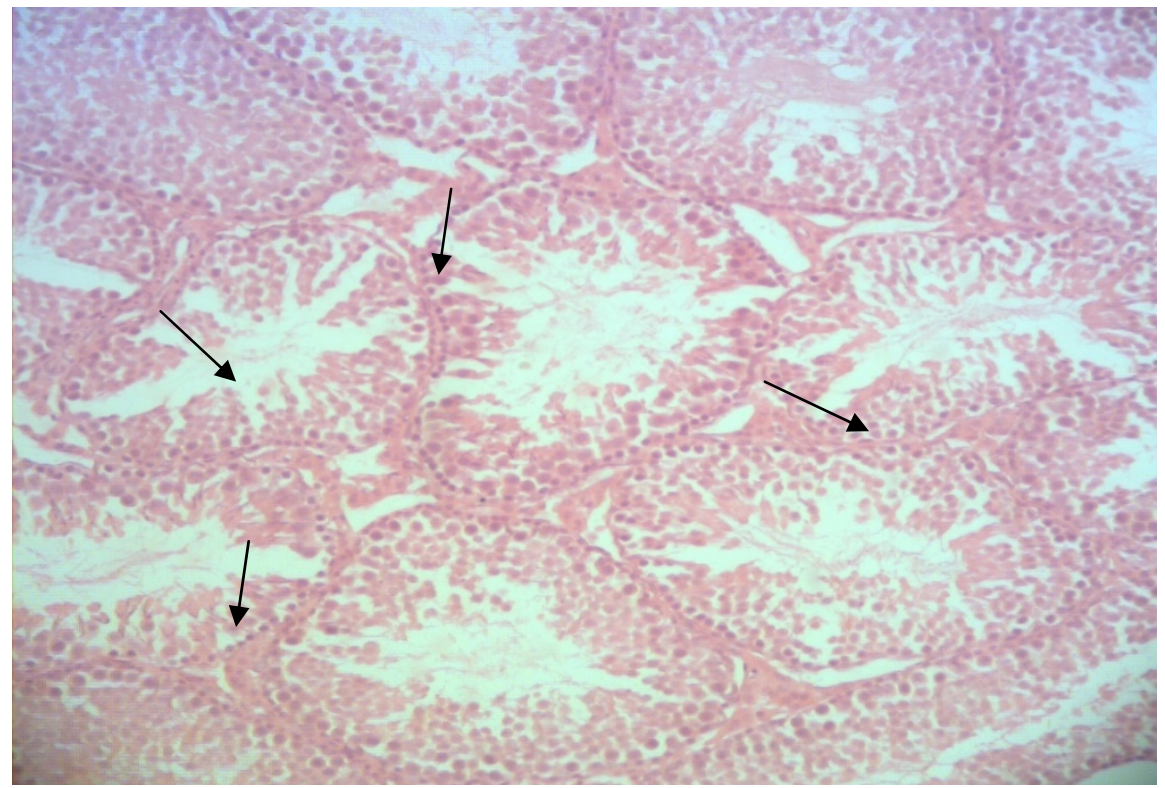

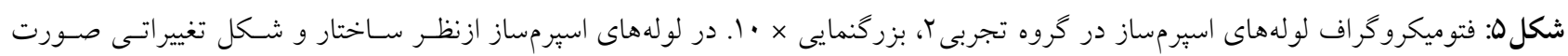

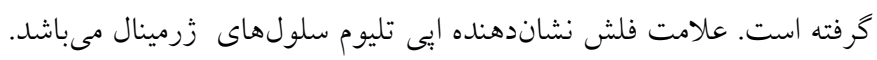

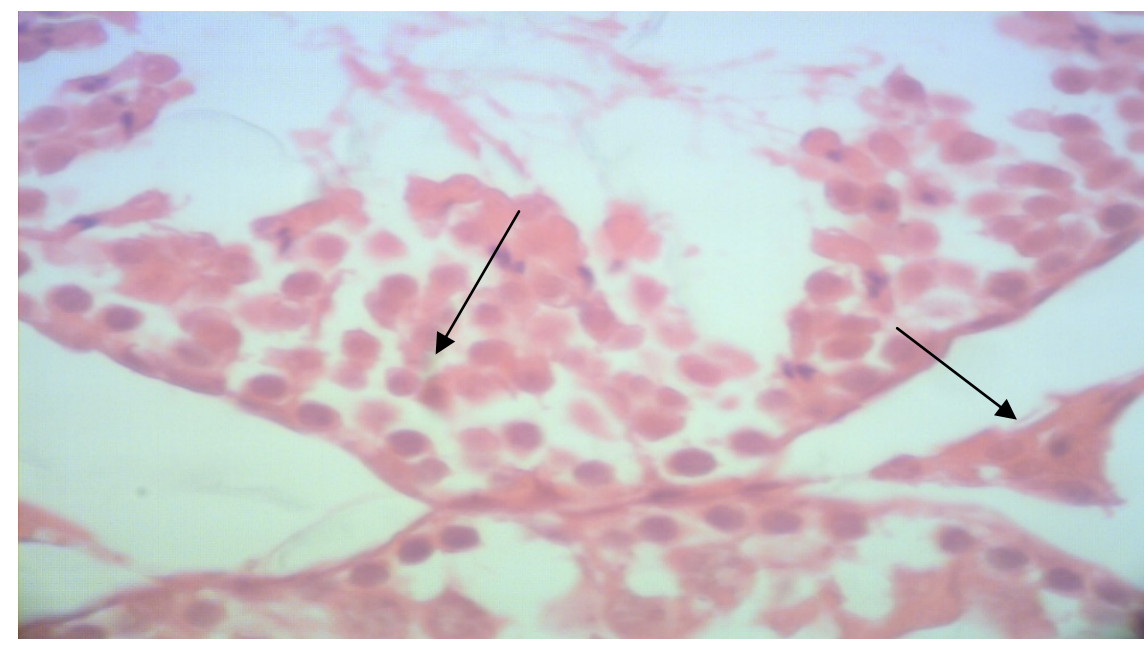

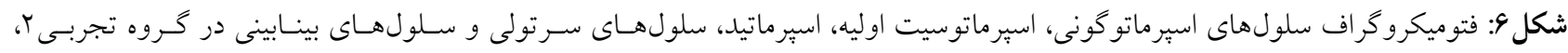

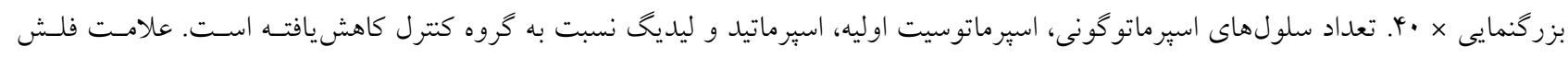

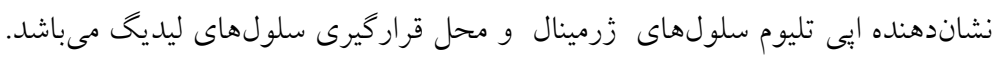




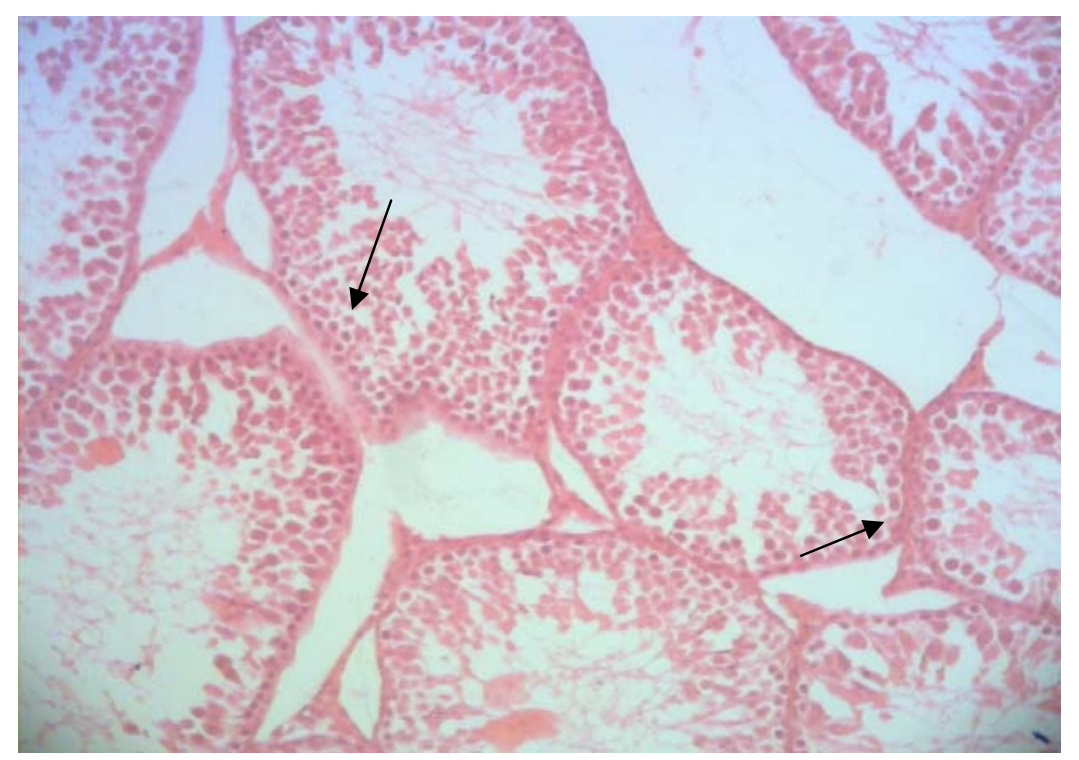

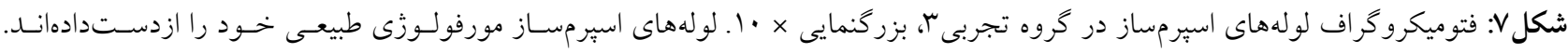

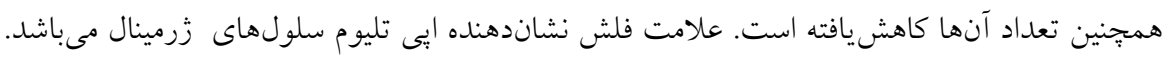

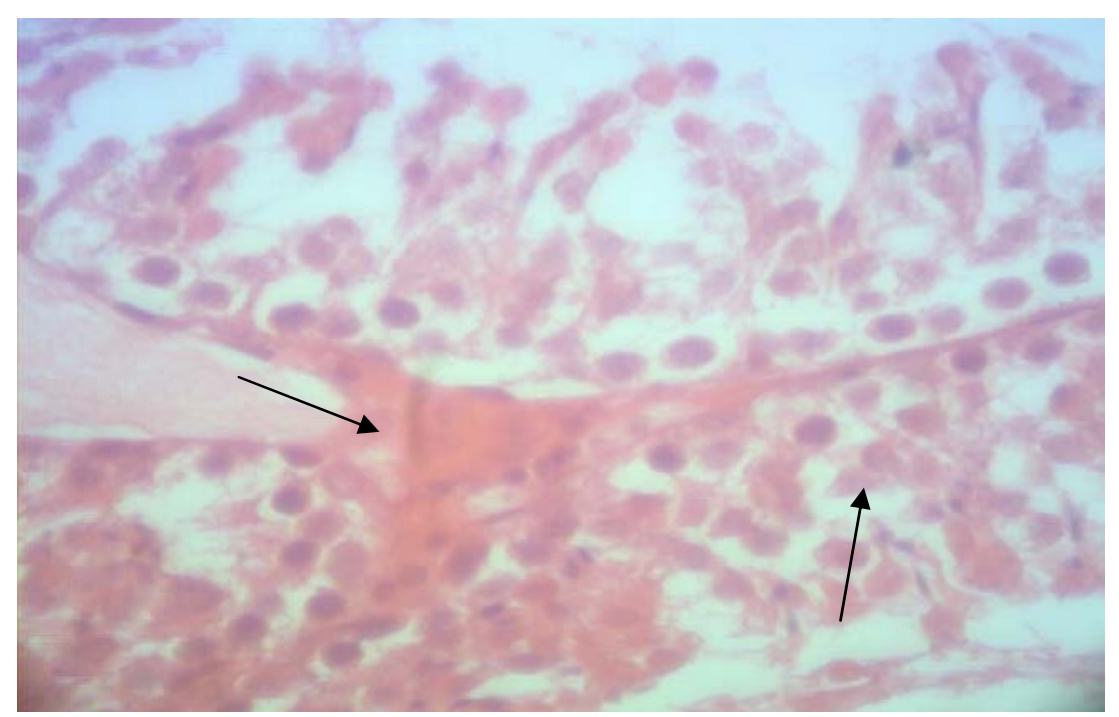

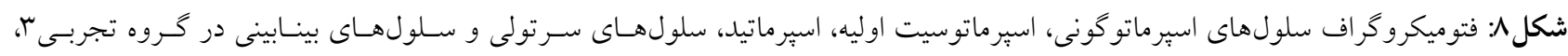

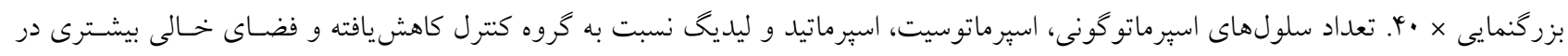

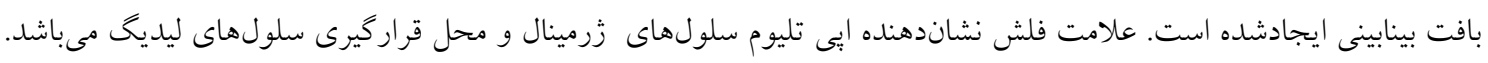

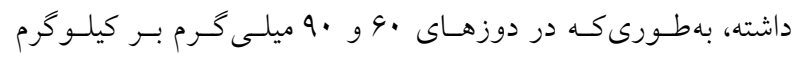
بحث و نتيجه كيرى

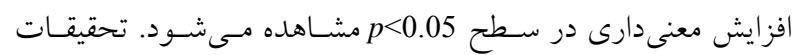

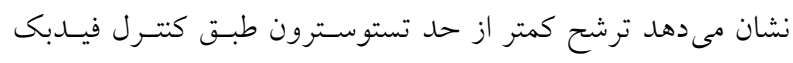

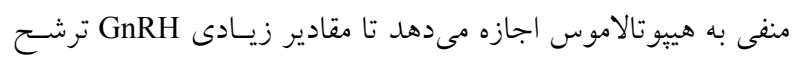

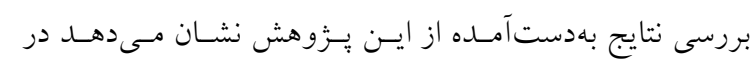

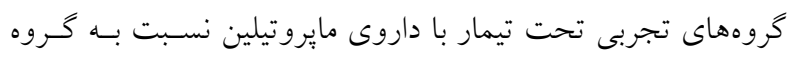

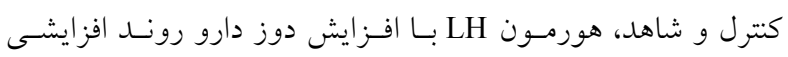


مقايسه با كروه كنتـرل مشـاهده گرديـــ. مطالعـات نشـان مسى دهـــ

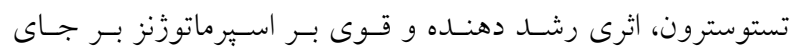

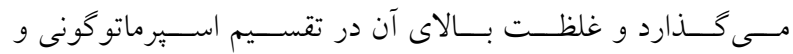

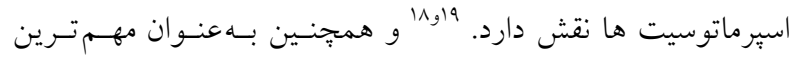

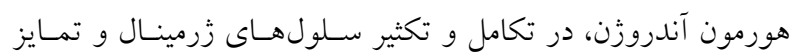
اسبرماتيدهاى كرد به اسـيرماتيدهاى كشـيده، نقـش اساسـى را ايفـا مى كند. ‘با توجه به كاهش تستوسترون در مطالعه حاضـر، احتمـالاً

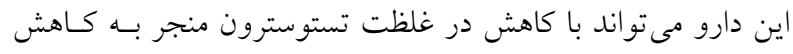

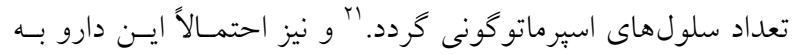

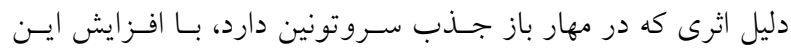

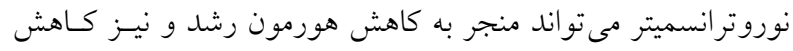

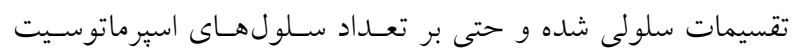

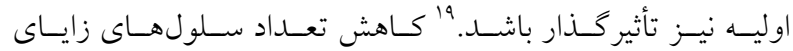
اسبرماتوكونى، اسبرماتوسيت اوليه و اسبرماتيد مسى توانــ درنهايـتـ منجر به كاهش تراكم اسيرمها شود. با توجه به اينكه تستوسترون از

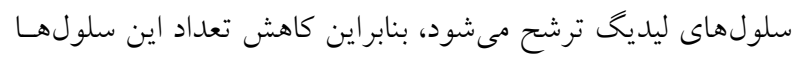

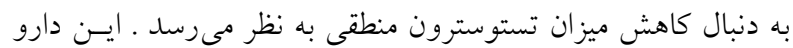

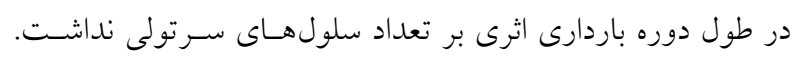

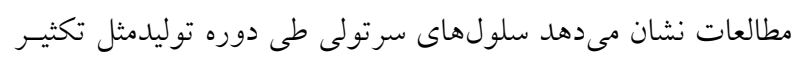

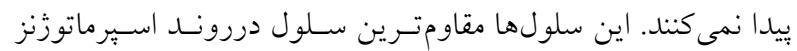

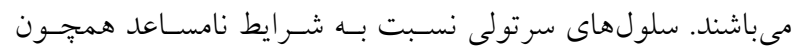
سوءتغذيه، عفونت و اشعه X مقاوم بوده و بِ يسازاين شـرايط بسـيار

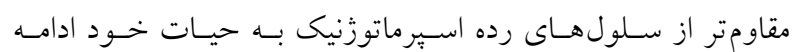

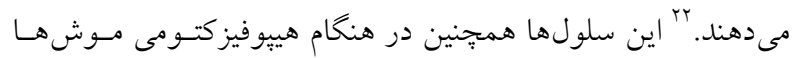

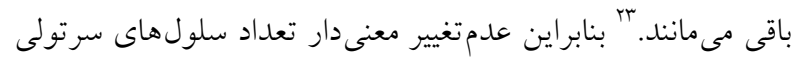

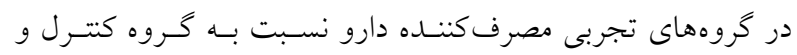

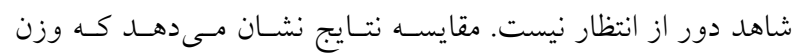
كروههاى تجربى دريافت كننده دارو نسبت به گروه كنترل و شـاهد

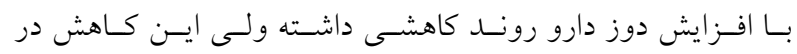

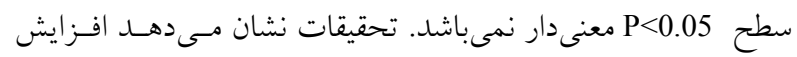

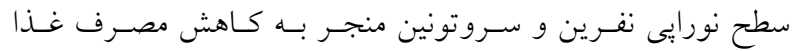

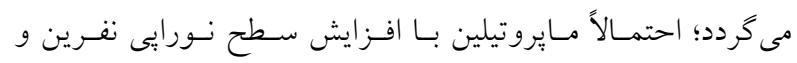
سروتونين در كوتاهمــت باعـث كـاهش اشـتها و نيـز كـاهش وزن

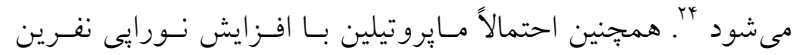

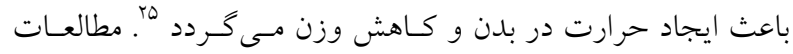

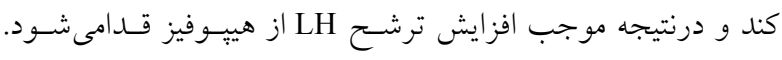

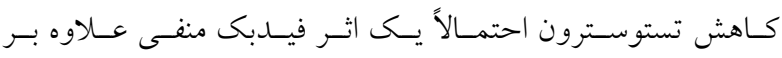
هييوتالاموس، بهطور مستقيم بر هيبيوفيز قــامى دارد و احتمـالاً ايسن

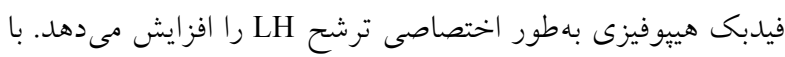

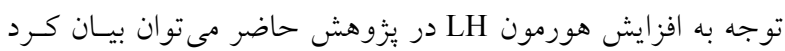

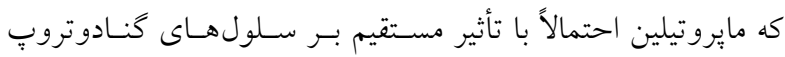

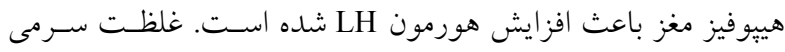

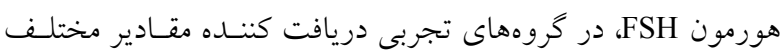

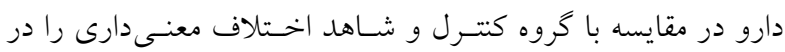

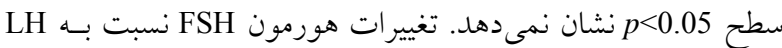

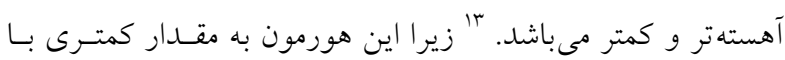
ترشح نوسان دار هورمون GnRH مترشحه از هييوتـالاموس ارتبـاط دارد و به آهستخى و در طى مدتزمان بيشترى در باسخ به تغييرات

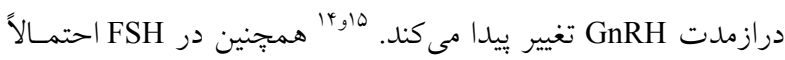
مكانيسم فيدبكى فقط توسط استروئيدهاى بيضهاى انجام نمسى شـود

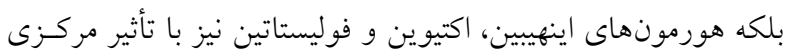

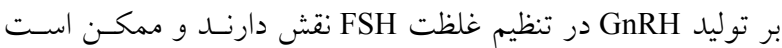

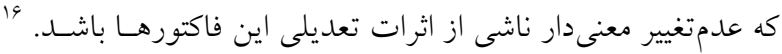

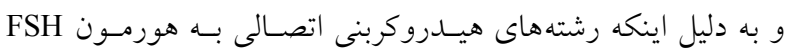

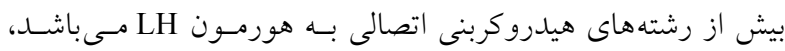

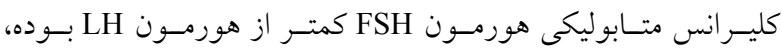

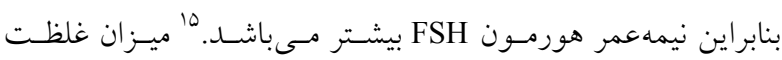

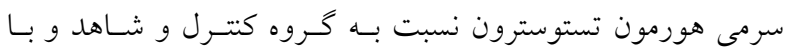

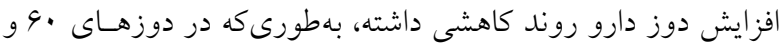
•9 ميلى گرم بر كيلوكرم كاهش معنى دارى در سـطح

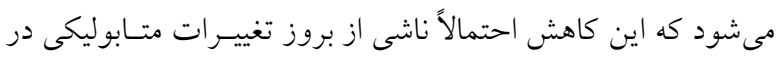
سلولهاى بينابينى بافت بيضه مى باشد. همجنين اين دارو با مهار بـاز جذب سروتونين باعث افزايش سطح اين نوروترانسميتر مسىشـود و

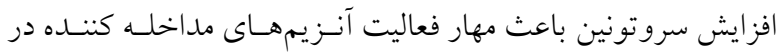
مسير توليد استروييد بافت بيضه مىشود و كاهش تستوسترون را بــه دنبال دارد. در بررسى مقـاطع بـافتى بيضـه، كـاهش معنسى دارى در تـراكم

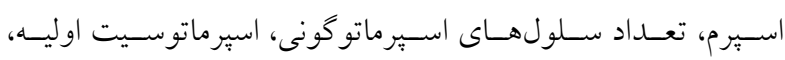
اسبرماتيد و نيز سلولهاى ليديخ در گروههاى تجربى دريافت كنتده

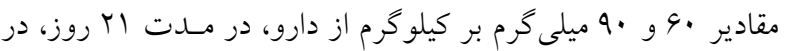


از اركانهاى بدن كاهش دهند؛ و با توجه به اينكه در تحقيق حاضـر

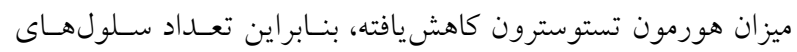

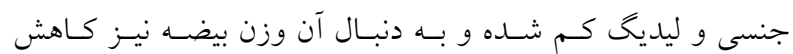
مى يابد.

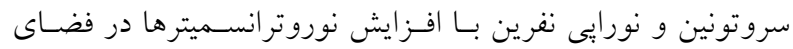

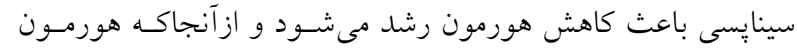

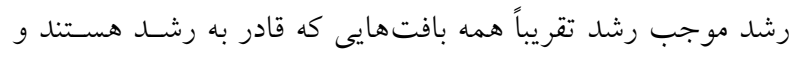

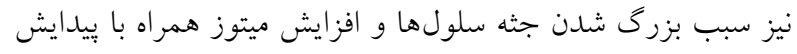

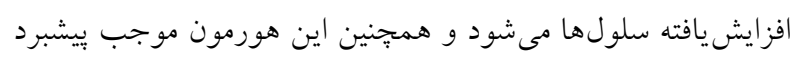

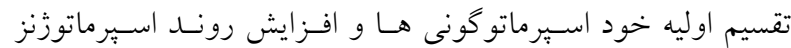
مىشود، بنابر اين باعث كاهش وزن بيضه شده است. 19 ولى به دلي ديل

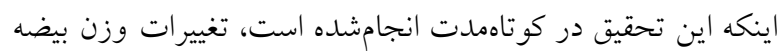

$$
\text { جشمخير نمىباشد. }
$$

با توجه به نتايج بهدست آمده جنين نتيجـهـ گيـرى مسى شـود كـه مصرف داروى مايروتيلين در دوز و مدتزمان زيـاد باعـث كـاهش

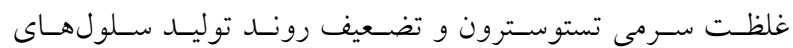

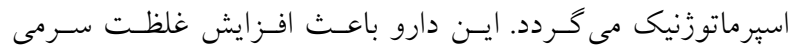
هورمون LH شده كه اين نشاندهنده فعاليت جبرانسى غـده هيبـوفيز بر اساس تأثير بذيرى آن در برابر داروى مايروتيلين اسـت. بنـابراين

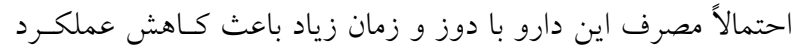
توليدمثلى و احتمالاً تخريب كامل بافـت بيضـه مسى شـود؛ زيــرا در

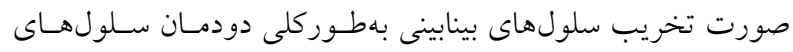

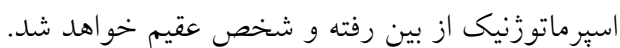

\section{تشكر و قدردانى}

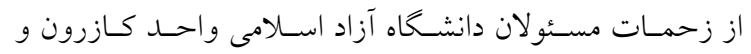

تمامى كسانى كه به نحوى ما را در انجام اين بيزوهش يارى كردهاند

$$
\text { سياسخزارى مى شود. }
$$

\section{References}

1. Veith, RC., Raskind, MA., Barenes, RF., Gumbrecht, G.,Raskind MA,Barnes RF,Gumbrecht G, Ritchie JL, Halter JB. Tricyclic antidepressants and supine, stading, and exercise plasma norepinephrine levels. Clin Pharmacol Ther.1983; 2983; 33(6): 763-9.

2. Peng, Wen-Huang; Kuan-Lin Lo, Yi-Hsuen Lee, TaiHuang Hung, Ying-Chih Lin"Berberine produces
نشان مىدهد افزايش ترشـح هورمـون تستوسـترون باعـث افـزايش

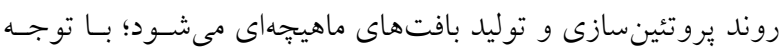

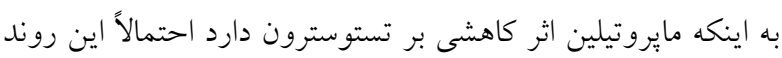

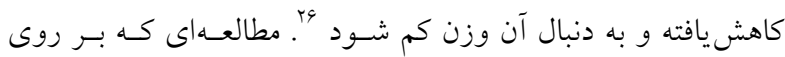

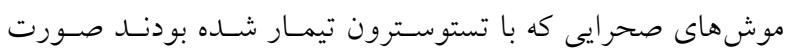

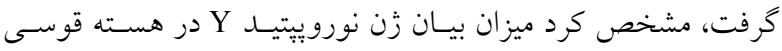

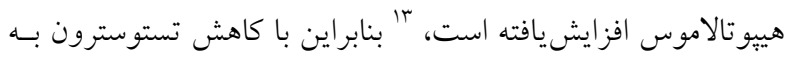

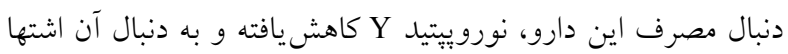
و نيز وزن كاهش مى يابد. تحقيقات نشان داده كيرندههاى سروتونين

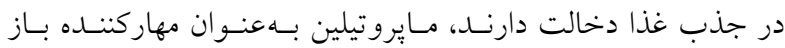
5- Hydroxy Tryptamine جذب سروتونين باعث مهار گيرندههـاى

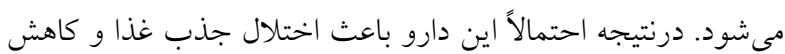

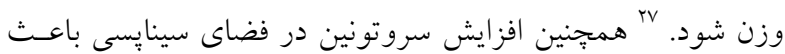
كاهش هورمون رشد و احتمالاً باعـث كـاهش وزن مسى شــود.

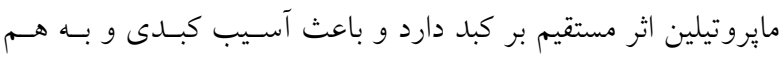

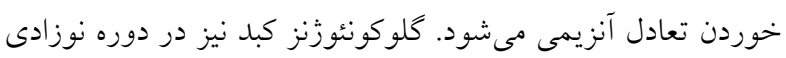

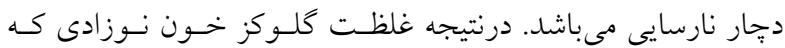
هنوز تغذيه نشده كاهش يافته و نوزاد قبل از اينكه بتواند تغذيه انجام

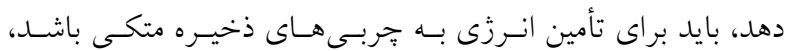
درنتيجه كاهش وزن ديده مسىشـود. "ازآنجاكـه افـزايش اشـتها و همجنين وزن از عوارض جانبى داروى مايروتيلين مى باشد، بنابراين با توجه به مطالب بيانشده و اينكه دارو در كوتاهمدت اسـتفادهشـده

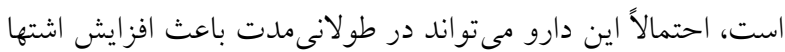
و وزن كردد كه اين افزايش مىتواند ناشى از احتباس آب يا مصرف

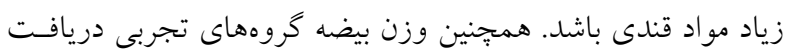

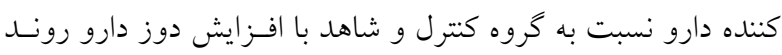
كاهشى داشته ولى اين كاهش در سطح

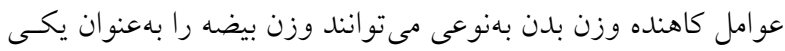

antidepressant-like effects in the forced swim test and in the tail suspension test in mice". Life Sciences. 2007;81 (11): 933-938.

3. Matthys A, Haegeman G, Van Craenenbroeck K, Vanhoenacker P. "Role of the 5-HT7 receptor in the central nervous system: from current status to future perspectives". Mol. Neurobiol.2011; 43 (3): 228-53. 
4. Alkalay D,Wagner WE,Carlsen S,Khemaani L,Volk J,Bartlett MF,Lesher A.Bioavailability and kinetics of maprotiline.Clin Pharmacol Ther.1980;27(5):697-703.

5. Sadock BJ, Sadock VA. Kaplan and Sadock's Synopsis of Psychiatry: Behavioral Sciences/Clinical Psychiatry. 9th ed. Philadelphia: Lippincott Williams \& Wilkins. 2002; P.534-5.

6. Shigeru Morishita, Seizaburo Arita. The use of maprotiline for major depression: a clinical report of 62 cases. The Journal of Applied Research. 2004; Volume 4, Number 2: Pages $252-256$.

7. Szegedi A, Wetzel H, Angersbach D, Philipp M, Benkert O. Response to treatment in minor and major depression: results of a double-blind comparative study with paroxetine and maprotiline. J Affect Disord. 1997; 45(3):167-78

8. Vaz-Serra A, Figueira ML, Firmino H, Albuquerque AJ, Jara JM, Pestana LC. Multicenter double-blind study of moclobemide and maprotiline. Clin Neuropharmacol. 1994; 17 Suppl 1:S38-49.

9. Emrich H M, Berger M, Riemann D, Von Zerssen D. Serotonin reuptake inhibition vs. norepinephrine reuptake inhibition: a double-blind differential-therapeutic study with fluvoxamine and maprotiline in endogenous and neurotic depressives. Pharmacopsychiatry. 1987; 20:603.

10. Kasper S, Dotsch M, Kick H, Vieira A, Moller HJ. Plasma concentrations of fluvoxamine and maprotiline in major depression: implications on therapeutic efficacy and side effects. Eur Neuropsychopharmacol. 1993; 3(1):13-21.

11. Li SW, Yan HQ. Maprotiline (Ludiomil) treatment of mental depression--a clinical report of 65 cases. Proc Chin Acad Med Sci Peking Union Med Coll. 1989; 4(3):139-41.

12. Jose Alves Gurgel,Roberto Cesar Prriera LimaJunior,Cristiano Oliviera Rabelo,Breno Bezerra Gomes Pinho Pessoa,Gerly Anne Castro Brito,Ronaldo Albuquerque Ribebeiro. Amitriptyline,clomipramine, and maprotiline attenuate the inflammatory response by inhibiting neutrophil migration and mast cell degranulation.Rev Bras Psiquiatr.2013; Vol.35. no.4.

13. Francois Pralong., The hypothalamo-pituitary-gonadal axis. Training Course in Sexual and Reproductive Health Research. 2009, February23, Geneva.

14. Elizabeth, S., Effect of selection for testosterone production on testicular morphology and daily sperm production in pigs, (Dr. Joseph Cassady). J. Anim. Sci. 2004; 82:2259- 2263.

15. Turek, Paul. J, Hypothalamic- Pituitary- Gonadal axis and control of spermatogenesis, director male reproductive Laboratory. Department of Urology university of California at Sanfrancisco. 2000;455-458.
16. Huntanieme I., Bartke A., Prespective;male reproduction.Endocrinology. 2001;142(6):2178-83.

17. Hedger MP. Khatab S. Gonzales G. de Kretser DM. Acute and short-term actions of serotonin administration on the pituitary-testicular axis in the adult rat. Reprod Fertile Dev.1995; 7: 1101-1109.

18. Meistrich, ML., Kanganiemi, M., Hormone treatment after irradiation stimulates recovery of rat spermatogenesis from surviving spermatogonia, Journal of Andrology. 1997;18:80-87.

19. Yu Y, Wong AO, Chang J P. Serotonin interferes with $\mathrm{Ca} 2+$ and $\mathrm{PKC}$ signaling to reduce gonadotropinreleasing hormone- Stimulated GH secretion in goldfish pituitary cells.Gen Comp Endocrinol. 2008;159: 58-66.

20. McLachlan RI, O’Donnell L, Meachem SJ, Stanton 1$3 \alpha$ - hydroxysteroid dehydrogenase tification of specific sites of hormonal regulation in spermatogenesis in rats, monkeys, and man. Recent Prog Horm Res. 2002; 57:149-79.

21. Guyton, Arthur C., Hall., John E. Medical physiology, Farrokh Shadan. M. D. Tehran. 2009.[In Persian]

22. Walker, William. H., Molecular mechanism controlling sertoli cells proliferation and differentiation, Endocrinology. 2003;144(9):3719-21.

23. Plant, T M., Marshall GR., The functional significant of FSH in spermatogenesis and the control of its secretion in male primates.Endocr Rev. 2001;22(6):764-86

24. Alemeida RG, Florio, JC., Spinosa, HS., Bernardi, MM., Comparative effects of maternal prenatal and postnatal exposures to astemizole on reproductive parameters of rats. Neurotoxicol Teratol. 2002; 24(2);255-65

25. Anunciacion, Lafuente., Nuria, Marquez., Maria, PerezLorenzo., David, Pazo and Ana I, Esquifin., Cadmium effects on hypothalamic- pituitary- testicular axis in male rats, Experimental Biology and Medicine. 2001;226:605611.

26. Jeffrey, R., Gingrich, M. D., Testicular disorders and clinical conferences. 2003. Available from. www. Vt men. edul/ Endocrinology/ Endocrine 20 Pathophysiology/ chap 2012; $20 \mathrm{htm}$.

27. Abdle, Ennaceur., Daniele, E., Dela, Gandaraj., Lautz, M., Introduction, pharmacology. Pharmrco. 2006; 50(2):2003

28. Kirchheiner, J., Heneckel, HB., Franke, L., Meineke, I,. Tzvetkov M, Ubelhack R, Roots I, Brockmoller J. Impact of the CYP2D6 ultra- rapid metabolizer genotype on doxepin pharmacokinetics and serotonin in platelets. Pharmacogenet Genomics. 2005; 15(8):579-87.

29. Dostal, LA., Chapin, RE., Stefanski, A., Harris, MW., Schwetz, BA., Testicular toxicity and reduced sertoli cell numbers in neonatal rat by (2- ethyl hexyl) and recovery of fertility as adult. Toxical Appl Pharmacol. 1988; 95(1):104-21. 